\title{
Deconstructing the Archetypal Self-Other Dichotomy in William Shakespeare's The Tempest
}

\author{
Marwan Harb Alqaryouti ${ }^{1} \&$ Hanita Hanim Ismail $^{2}$ \\ ${ }^{1}$ Department of English Language, Literature and Translation, Zarqa University, Zarqa, Jordan, and Centre of \\ English Language Studies Faculty of Languages and Communication Universiti Sultan Zainal Abidin, Kuala \\ Terengganu, Terengganu, Malaysia \\ ${ }^{2}$ Centre of English Language Studies Faculty of Languages and Communication Universiti Sultan Zainal Abidin, \\ Kuala Terengganu, Terengganu, Malaysia \\ Correspondence: Hanita Hanim Ismail, Centre of English Language Studies Faculty of Languages and \\ Communication Universiti Sultan Zainal Abidin, Kuala Terengganu, Terengganu, Malaysia. Tel: 6019-976-2206. \\ E-mail: hanitaismail@unisza.edu.my
}

Received: May 15, 2018 Accepted: September 23, 2018 Online Published: September 25, 2018

doi: 10.5539/elt.v11n10p139 URL: http://doi.org/10.5539/elt.v11n10p139

\begin{abstract}
Shakespeare's The Tempest (1610-1611) is one of the controversial plays regarding whether to be placed in the purview of colonialism or anti-colonialism. The bard sketches two antithetical characters in the course of the play, Prospero and Caliban, who form the two extremes of the self against the other dichotomy. This study aims at proving Shakespeare's proclaimed presuppositions at the realm of colonialism through his attempt to deconstruct the dichotomic discourse of colonialism via these two characters. The study also explains how the play starts with structuring two binary-oppositional spheres to lead readers eventually to question the very purpose of colonialism, which dehumanizes the colonized people. The data used in this study are generated through both primary and secondary sources of data collection, (i.e. the paly and other studies that give input to the discourse of the study). The paper moreover, focuses on Abdul R. JanMohamad's concept of Manicheanism allegory to examine the backdrop of postcolonial view of self/other dichotomy. A critical discourse narrative technique is employed in the discussion section of the study based on the deconstruction apparatus, such as binary opposition, Manicheanism allegory and symbolism. The study also refers to Shakespeare's symbolism of Prospero as a character who can be perceived as Columbus himself, and consequently as the representative of the colonial enterprise. At the end of the play, therefore, the language of Prospero becomes noticeably less hegemonic, as he realizes that the individuals on the island should be emancipated from his dominance. In this way, Prospero becomes the mouthpiece of Shakespeare himself, who conveys counter-colonial beliefs, such as the confusion of the biological and the cultural, and the colonizers' claim of their superiority, over the colonized; and thus, their right to dominate.
\end{abstract}

Keywords: shakespeare, the tempest, post-colonialism, mimicry, manicheanism, binary oppositions, deconstruction

\section{Introduction}

\subsection{The Colonial Zeitgeist of the Tempest}

Christopher Columbus's so-called discovery of America in 1492 marked a turning point in the history of colonialism. The sea traveler embodied the European colonial desire for expansion; an enterprise that strived to make the Western culture hegemonic through usurping the sources of the New World, wiping away cults among its natives and replacing it with Christianity. Greed was conspicuous in Columbus' mission; his diaries reveal that his main interest was ruling the land, and increasing the wealth of Europe through searching for gold.

When Columbus encountered the natives of the new territories, he completely dehumanized them. He portrayed them as beasts that are inferior to human beings; hence, a self-other dichotomy was created for colonial purposes. The binary oppositions tally with the colonial discourse which serves the metropolis and legitimizes imperialism. This means that there are two purposes of colonialism as Abdul JanMohamed classifies them; the "overt", which claims that it is a civilizing mission that aims at helping the natives to lead better lives, and the "covert" purpose, 
which is the ulterior motive that the colonizer has; to exploit the resources of the land, and expand the empire (Abdul, 1985).

After the death of HRM Queen Elizabeth I in 1603, King James I ruled England. At that time, England was financially exhausted, and the English began to consider usurping the resources of other territories, such as India, the Middle East and the New World, to enrich the empire. In 1609, the first English colony, Virginia, was established in America; only two years before the appearance of Shakespeare's The Tempest on stage. Consequently, it is highly significant to consider the historical context of colonialism when interpreting The Tempest.

The Tempest is Shakespeare's swansong to the stage. It is a romance tragicomic play written in 1610-1611. Garber (2008) classifies The Tempest as "a comedy that recuperates what could have been a tragedy." She also adds that the play "belongs ... to the genre of revenge play" (Garber, 2008; Loc. 540). The events are set in an isolated island in the Mediterranean Sea. The story begins with a storm striking a ship that carries a group of men, Alonso, Ferdinand, Antonio, Sebastian, Stephano, Gonzolo and Trinculo, who are on their way from Tunis to Italy. It becomes obvious that Prospero - Alonso's brother, is the one who has raised the tempest with his magical power, with the help of Ariel, the airy spirit. Prospero does so because Alonso has deposed him from Naples, where he is the rightful king. He has lived on the island for twelve years with his daughter Miranda after banishing Sycorax, the owner of the island, and compelling her son, Caliban, to serve them.

The play, then, becomes complex in its three subplots. The first plot depicts Caliban's miserable status as an inferior creature, and his failed attempt to rebel with the help of Stephano and Trinculo. The second plot is the love relationship between Ferdinand and Miranda, which ends with the marriage of the couple. The third plot is the conspiracy of Gonzalo and Sebastian to kill Alonso; a conspiracy that Prospero thwarts with his magic. All of the subplots are controlled by Prospero - the super powerful figure, who brings everybody together in the end of the play, and decides to forgive them.

\subsection{Literature Review}

Given the historical context and the plot of the play, it seems plausible that Shakespeare did not write the play in vacuum; he was profoundly influenced by the colonial milieu of that time, particularly the voyages of exploration and the missionaries. Critics, therefore, have been aware of the colonial attitude of the play, and several postcolonial studies have approached The Tempest as a play that falls in the purview of colonial literature.

Hulme (1986), for instance, discusses colonialism in The Tempest in his book Colonial Encounters: Europe and the Native Caribbean, 1492-1797 where he investigates the connection between the historical context of colonialism and the play in the third chapter of his book Prospero and Caliban. The chapter is written in a comprehensive manner, focusing on the play from a colonial perspective. In the beginning of the chapter, Hulme scrutinizes the influence of zeitgeist of colonialism onto the events, including the title of the play. He then discusses on the issue of Otherness and identity crisis, which are the practices of colonialism where he finally argues that Caliban's language is charged with a revolutionary spirit, which may allow him to regain his identity.

This leads to another study by Sarnecki (2000) who compares Shakespeare's The Tempest to Aimé Césaire's $A$ Tempest (1969). In her essay Mastering the Master: Aime Cesaire's Creolization of Shakespeare's "The Tempest", she argues that Shakespeare's play is a colonial text, while Césaire's is a prequel text that gives Caliban a voice and an identity by making him the protagonist. Moreover, she argues that Prospero is "the alter-ego of Shakespeare" himself (p. 281), whose magic is playing with words, and creating images through language. She also believes that Shakespeare represents the Western thought, while Césaire represents that of the other.

This study, however, focuses mainly on the characters of Prospero and Caliban as two antithetical characters portrayed for the readers, in juxtaposition to delineate the overt purposes of colonialism. The study proves that Shakespeare's The Tempest attempts to contour a structuralist paradigm in hope to come up with a deconstructionist conclusion. That is to say that the two main characters, Prospero and Caliban, are sketched as archetypal binary oppositions, where Shakespeare aims to show to the readers the chasm that colonialism creates between what is so-called self-other relationship. In the end of the play, however, readers sense a deconstructionist call that Shakespeare conveys through the language of Prospero, who breaks away from his magic, and orients his power to be personal rather than hegemonic.

\section{Methodology}

One of the contending issues in literary studies is the question of methodology and theoretical approach which to some extent, refers to the same thing in the study of literature. In general, research methods are the approaches employed by a researcher to collect the data. As Dawson $(2009$, p. 27) postulates that "the philosophy or the 
general principle which will guide your research. It is the overall approach to studying your topic and includes issues you need to think about such as the constraints, dilemmas and ethical choices within your research". The data in the study of literature are generated from two sources - primary and secondary sources. On one hand, a primary source is an original object or document - the raw material or first-hand information. It usually refers to the original manuscript, such as play, prose and biography or autobiography of an author, in literature studies (Wolfreys, 2010). On the other hand, a secondary source refers to something written about a primary source, which include comments on, interpretation of, or discussions about the original material. It can also be a journal article, book, or collection of essays (Wolfreys, 2010; Rainsford, 2014).

Henceforth, the data used in this study are generated through both primary and secondary sources of data collection, (i.e. the play and other studies that give input to the discourse of the study). The paper moreover, focuses on Abdul R. JanMohamad's concept of Manicheanism allegory to examine the backdrop of postcolonial view of self/other dichotomy where "the post-colonial perspective is the reclamation of the voice(s) and experiences of the 'other' "(Rivkin \& Ryan, 2017, p. 257). A critical discourse narrative technique is employed in the discussion section of the study based on the deconstruction apparatus, such as binary opposition, Manicheanism allegory and symbolism. Binary opposition techniques are used to compare between Prospero and Caliban in this study. These are deconstruction techniques which Derrida discusses about based on Saussurean notion of difference in correlation with philosophical concepts. "Like signs in language", Derrida argues, "they too are given identity by their differences from one another' (as cited in Rivkin \& Ryan, 2017, p. 271).). In this study, the two characters symbolize two different worlds - Europe as the Self, and the Third World as the 'other'.

\section{Result and Discussion}

\subsection{The Dichotomic Discourse of Colonialism}

Although Darwinism appeared after Shakespeare's The Tempest, it remains relevant to the theory of evolution because it features Caliban as a lesser developed creature than Prospero. Garber (2008) argues that Caliban is "related to beasts, fish, and animals" (loc. 557), which makes his inferiority unconsciously justified by readers. As Caliban is animalized, he lacks the humane quality within a proper human civilization, such as a developed language, an independent identity and an acknowledged religion. As such, he seeks to learn Prospero's language and culture in order to promote his low status. Structurally speaking, a prompt superior-inferior dichotomy is created in the minds of readers, who automatically link Caliban to the absence of civilization and Prospero to its presence. Nevertheless, this paper contests that by creating such dualism, Shakespeare grabs readers' attention to the stereotypes that the colonial discourse creates, since the binary oppositions take readers to extreme cases of both, the colonizer and the colonized. To put it clearly, Shakespeare does not present two realistic characters; but rather two extreme ones. In this case, he draws vivid pictures of the two sides of the formula, which makes readers question about the whole structure of the colonial discourse.

One example of such extremes is Caliban's attempt to rape Miranda, which confuses readers, whether to blame Caliban for this shameful crime, or to accept it since he is not well-developed as a human being. The play, thus, raises the question of whether criminal acts are biological or cultural, which is a crucial question in the discourse of colonialism. Fanon asserts in his book The Wretched of the Earth (1961) that criminality is not a biological innate feature; the colonized people rather acquire it due to the oppression that they experience. He also asserts that "[w]hoever says rape says Negro" (p. 166), whose target is a white "anima," Miranda in Caliban's case, who makes the dreams of the oppressed black come true (p. 189). Readers realize, however, that Caliban commits the crime for cultural reasons since he is mistreated.

Prospero, on the other hand, is an example of a good leader who is qualified to rule the island. He is portrayed as the tolerant leader who forgives everyone in the end because he is the white man who has the higher and more civilized values. In colonial texts, morals are viewed as genetics, rather than acquired. That is to say that civilization is inherent to the colonizer, while barbarism is an innate characteristic of the colonized, who is placed at the bottom of the Great Chain of Being. In science, however, this is not the case. Young (1995), for example, refutes the racial claim that morals are biological. This paper also argues that Shakespeare mocks this radical idea by featuring Caliban as a literally deformed creature.

Shakespeare, moreover, reveals the dangers of rejecting the other in a society through the character of Prospero. According to JanMohamed's classification of colonial fiction, The Tempest is considered as an "imaginary" work. $\mathrm{He}$ argues that the "adamant refusal to admit the possibility of syncretism of a rapprochement between self and other, is the most important factory distinguishing the 'imaginary' text" (p. 73). JanMohamed calls this rejection of the other, that is based on the Self-Other contradictory features, the Manichean Allegory. In the play, Prospero is 
the colonial self who ultimately refuses to be compared to Caliban. Nevertheless, Prospero still represents enlightenment, knowledge and tolerance, while Caliban represents darkness, ignorance and barbarism.

An analysis of binary oppositions thus, are present whenever Prospero and Caliban are compared. The two characters symbolize two different worlds - Europe as representing the self, and the Third World as the other. Prospero's magic is equivalent to the European technology, as it enables him to compel the others and claim for the possession of the island. Widening the gap between the two axes, however, contribute to questioning the validity of such dichotomy.

\subsection{The Archetype of the Colonizer}

The archetype of a colonizer is established from the very beginning of the play, starting with the very title, The Tempest, which is influenced by the colonial spirit of the period. Hulme (1986) asserts that "[s]torms were familiar from the Mediterranean and the eastern Atlantic" (p. 94). A hurricane in 1502, for instance, "destroyed the fleet of Columbus' enemy." The ship that carried Columbus' personal fortune, however, was the only surviving ship. As such, he was "accused of being a magician...having summoned the hurricane to strike down his enemies" - a superpower to control other elements, including nature and human (p. 95). Accordingly, Prospero in the play is a reference to Columbus himself, as the former raises the tempest through his magic in the beginning of the play.

Prospero's colonial attitude is present in the play. He is the embodiment of the European colonizer, who unjustly usurps the land and subdues its people. It is obvious in the play that though Prospero has spent twelve years on the island, which he does not consider as home, but rather as a colony - a place of self-empowerment. This reflects the colonial mentality that always yearns for the mother country, which is Milan or Naples in the play, as a metropolis. Prospero, therefore, never talks about the island positively; he refers to it as "a poor cell" (The Tempest, I, 2: 107), and he plans to leave once his mission is accomplished.

Italy in the play stands for the civilized values; and even Prospero's name is an approximate to the word "prosperous". While the island stands for the barbarian other, and not surprisingly, Caliban's name reflects inferiority, as it is close to the word "cannibal". The island is the contact zone where the colonizer and the colonized coexist. This coexistence, however, is not based on equity and tolerance, but rather on a master-slave relationship.

Prospero perceives himself as the master, who is in charge of controlling the other. He is, to use Pratt's term (1992), the "seeing-man" who seeks to possess whatever his eyes see (p. 6). With this colonial gaze, Prospero regards the island as a terra incognita; consequently, he pretends to be the owner of the island, and disregards the rights of its natives, who are regarded as the other, after Prospero's arrival. When Prospero first arrives at the island, he tries to make a good relationship with Caliban, the original owner of the land. Caliban says addressing Prospero:

Thou strok'st me and made much of me: wouldst give me

Water with berries in't, and teach me how

To name the bigger light, and how the less,

That burn by day and night: and then I lov'd thee. (The Tempest, I, 2:333-336)

Prospero, thus, has colonial tactics to take over the island. He hides his evil intentions when he first arrives by treating Caliban well and teaching him his own language. Through imposing his own language, culture and religion, Prospero is able to make of Caliban a servant, and to assert his inferiority. Caliban, therefore, becomes weak-kneed though he is supposed to be the master of the land; "[t]his island's mine, by Sycorax my mother,/ Which thou tak'st from me" (The Tempest, I, 2: 330-331), Caliban asserts. Although Caliban has his own religious belief, he becomes skeptical. He says, "I must obey: his art of such power,/ It would control my dam's god, Setebos,/ And make a vassal of him (I, 2: 372-375). Caliban, hence, is turned from a free citizen living on his land into a weak, inferior barbarian who needs to be civilized.

Believing in his superiority, Prospero refers to Caliban negatively, he tells him that "[ $t]$ hou poisonous slave, got/ by the devil himself" (I, 2: 317-318). Also, Prospero calls Caliban by different contemptuous names, such as, "my slave", "monster" and "demi-devil." Similarly, Miranda also has the same pejorative attitude towards Caliban when she expresses that she despises even to look at him. At the same time, Prospero and Miranda see the necessity of Caliban to remain available in order to serve them. Prospero says, "We cannot miss him: he does make our fire,/ Fetch in our wood and serves in offices/ That profit us" (I, 2: 311-312). Stephano, also, bluntly states that Caliban is "a present for any emperor" (II, 2: 67). All these magnifies Said's concept of exoticism, which is owned by Caliban. That is to say that he is feared and scorned because of his deformed body and distorted manners, but desired at the same time as he makes a good slave. 


\subsection{The Archetype of the Colonized}

Caliban perfectly fits in the picture of the other where he is perceived as inhumane. In many ways, he does not fit in the normal conception of a man. He is "disproportion'd in his manners/ As in his shape" (5: 291-292), a monster with four legs, making it lesser obvious whether he is a man or a fish. Trinculo also expresses this when he sees Caliban, "What have we here? a man or a fish! ... he smells like a fish ... this monster make a man" (II, 2: 24-26). As a result to this inferiority, Stephano claims that he is a protector of Caliban when he says, "[t]he poor monster's my subject and he shall not suffer indignity (III, $1: 34-35$ ). This protection is merely a justification of imposing superiority on Caliban.

Not only Caliban's outward appearance is portrayed to be deformed, but also his morals. He tries, for instance, to rape Miranda, and to kill Prospero - two deeds that are seemingly heinous if not regarded as part of Caliban's right to rebel against colonialism. Raping Miranda asserts a picture of savagery, owned by the other who cannot control his sexual desire. While conspiring to kill Prospero makes of Caliban an ungrateful servant. Unlike Ariel, the airy spirit, who represents the silent and subjugated colonized.

If such deeds, however, are interpreted under the umbrella of resistance, Caliban would be a victim of a colonial enterprise that seeks to deprive him of all his rights. As the archetype of the colonized natives, Caliban's voice is silenced in most of the scenes of the play. When he talks, however, a revolutionary spirit is sensed. This revolt is identifiable in lines that he expresses, such as "[y]ou taught me language, and my profit on't/ Is, I know how to curse" (I, 2: 363-364). It is his rebellious attempt to dismantle the power of the assumed binary oppositions, and shifts the perception of the events to the realm of deconstructing the hegemonic power of colonialism. Prospero imposes his own language because as Fanon puts it, language is power: "To speak means ... to assume a culture, to support the weight of a civilization" (1967, pp. 17-18). Caliban, consequently, does not exactly imitate what Prospero teaches him. Bhabha's concept of "mimicry" fits in this situation. In his case, the colonizer anticipates the colonized to imitate certain values, whereas the colonized is selective, and rebels against such values, or uses them in a way that does not please the colonizer. In the end of the play, Prospero's language also differs. He says to Ariel, for example, when he asks him to release everyone on the island:

Prospero: Go release them

Ariel: My charms I'll break, their senses I'll restore,

And they shall be themselves (The Tempest, V, 1: 720).

These lines reveal how Prospero's dominance is undermined at the end, as his charm, which represents his power, is broken by his own will. Another discourse is, therefore, created here which exhibits another type besides the dichotomic superior/inferior one. The fact that Prospero allows the inhabitants of the island to be "themselves" also reveals that they could now have their own identities, instead of being controlled by his power.

The finale of the play, as a result, also emphasizes the idea of deconstruction, as Prospero says in the epilogue: "Now my charms are all o'erthrown,/ And what strength I have's mine own,/ Which is most faint ... / But release me from my bands" (Epilogue: 82-83). The power that Prospero has is eventually restrained and oriented to himself rather than being transcended to the other. His call to "release [him] from [his] bands" is a rallying cry for emancipation, as he realizes that dominating the others and claiming superiority is an evil deed. There is, consequently, a call for establishing new identities for each individual in lieu of the self-other dichotomy.

\section{Conclusion}

In conclusion, Shakespeare is ahead of his time to introduce the self-other dichotomy through two opposite characters; Prospero and Caliban, and to outlook the dangers of such rift. This reveals that Shakespeare's portrayal is not a colonial one as much as it is anti-colonial or critical of colonialism because the binary opposition that he presents through these two characters makes the atrocities of colonialism crystal clear.

The building of the characters of Prospero and Caliban, therefore, highlights some implied messages that Shakespeare wants to convey. In other words, by scrutinizing the seemingly antithetical characters, then the concealed rebellious seeds in Caliban's language, and the dismantling power of that of Prospero, readers anticipate a deconstruction on the self-other dichotomy that has been structured in the play.

\section{References}

Abdul, R. J. (1985). The Economy of Manichean Allegory: The Function of Racial Difference in Colonial Literature. Critical Inquiry, 12(1), 59- 87. https://doi.org/10.1086/448321

Bhabha, H. (1994). The Location of Culture. London: New York. Routledge. 
Dawson, C. (2009). Introduction to research methods: A practical guide for anyone undertaking a research project. Oxford, UK, How to Books.

Fanon, F. (1967). Black Skins, White Masks. New York: Grove Press.

Garber, M. (2008). Shakespeare and Modern Culture. New York: Pantheon Books. Kindle 7.

Hulme, P. (1986). Colonial Encounters: Europe and the Native Caribbean (pp.1492-1797). London: Methuen.

Pratt, M L. (1992). Imperial Eyes: Travel Writing and Transculturation. New York: Routledge.

Rainsford, D. (2014). Studying Literature in English: An Introduction. New York, Routledge.

Rivkin, J., \& Ryan, M. (2017). Literary theory: an anthology. John Wiley \& Sons.

Sarnecki, J. H. (2000). Mastering the Master: Aimé Césaire's Creolization of Shakespeare's The Tempest. The French Review, 74(2), 276-86.

Shakespeare, W. (2004). The Tempest. Beirut: York Classics.

Willis, D. (1989). Shakespeare's Tempest and the Discourse of Colonialism. Studies in English Literature, 29(2), 277-89. https://doi.org/10.2307/450475

Wolfreys, J. (2010). The English Literature Companion. Palgrave Macmillan.

Young, R. (1995). Colonial Desire: Hybridity in Theory, Culture and Race. London: Routledge.

\section{Copyrights}

Copyright for this article is retained by the author(s), with first publication rights granted to the journal.

This is an open-access article distributed under the terms and conditions of the Creative Commons Attribution license (http://creativecommons.org/licenses/by/4.0/). 